\title{
Effect of Applied Ozone Dose, Time of Ozonization, and Storage Time on Selected Physicochemical Characteristics of Mushrooms (Agaricus bisporus)
}

\author{
Magdalena Zalewska *(D), Elżbieta Górska-Horczyczak (D) and Monika Marcinkowska-Lesiak
}

check for updates

Citation: Zalewska, M.; GórskaHorczyczak, E.; MarcinkowskaLesiak, M. Effect of Applied Ozone Dose, Time of Ozonization, and Storage Time on Selected Physicochemical Characteristics of Mushrooms (Agaricus bisporus). Agriculture 2021, 11, 748. https:// doi.org/10.3390/agriculture11080748

Academic Editor: Warwick Gill

Received: 28 June 2021

Accepted: 4 August 2021

Published: 6 August 2021

Publisher's Note: MDPI stays neutral with regard to jurisdictional claims in published maps and institutional affiliations.

Copyright: (c) 2021 by the authors. Licensee MDPI, Basel, Switzerland. This article is an open access article distributed under the terms and conditions of the Creative Commons Attribution (CC BY) license (https:/ / creativecommons.org/licenses/by/ $4.0 /)$.
Department of Technique and Food Development, Institute of Human Nutrition Sciences, Warsaw University of Life Sciences, Nowoursynowska 159c Street, 02-776 Warsaw, Poland;

elzbieta_gorska_horczyczak@sggw.edu.pl (E.G.-H.); monika_marcinkowska_lesiak@sggw.edu.pl (M.M.-L.)

* Correspondence: magdalena_zalewska@sggw.edu.pl

Abstract: The impact of ozone dose and time of ozonization on the selected physicochemical properties of Agaricus bisporus stored for 14 days in $2{ }^{\circ} \mathrm{C}$ was investigated. Mushrooms were subjected to gaseous ozone with increasing concentrations of $0.5,1.0$, and $2.0 \mathrm{mg} \mathrm{L}^{-1}$ and applied two times to ozonization: 30 and $60 \mathrm{~min}$. The following parameters were evaluated: weight loss, internal and external color $\mathrm{L}^{*} \mathrm{a}^{*} \mathrm{~b}^{*}$ parameters, overall color change $(\Delta \mathrm{E})$, browning index $(\mathrm{BI})$, firmness, total phenolic content (TPC), and total antioxidant activity (TAA). After storage, mushrooms had a higher level of firmness, especially for group ozonized with $2 \mathrm{mg} \mathrm{L}^{-1}$ for 30 or $60 \mathrm{~min}$. Mushrooms from group ( $1 \mathrm{mg} \mathrm{L}^{-1}$ ) subjected to ozonization within 30 and $60 \mathrm{~min}$ had a high ability to neutralize DPPH-free radical (42.45 \pm 0.43 and $41.34 \pm 0.29$, respectively). Exposure of mushrooms to ozone atmosphere does not cause large changes in quality and physical parameters of Agaricus bisporus.

Keywords: Agaricus bisporus; ozone; storage; color; physicochemical properties

\section{Introduction}

White button mushrooms belong to the Basidiomycota division and Agaricaceae family. They are included in the noblest and most valuable mushrooms from a nutritional point of view. They are rich in high quality proteins and contain amino acids such as lysine and tryptophan. A valuable component is ergosterol, which is converted in the human body to vitamin D [1]. Chen et al. [2], in their studies, assessed the healthful value of Agaricus bisporus and found them to be the best source of vitamin D among all products of non-animal origin. Mushrooms are a good source of dietary fiber, vitamin C, and B complex (riboflavin, niacin, folic acid, thiamine, pantothenic acid, cobalamin, and biotin) [3]. Singh et al. [4] describe mushrooms as the most sensitive product for storage from all horticultural products. It is important to select an air humidity and storage temperature to maintain the high quality of mushrooms because deterioration in the quality of mushrooms occurs in a short time after harvest. This is due to the high water content (ca. 90\%), high enzymatic activity, and possible rapid development of mold and bacteria [5]. The mentioned factors cause loss of color, browning, and weight loss and textural changes, which result in obtaining mushrooms with unsatisfactory appearance and which are unsatisfactory for consumption long-term [5]. Loss of water from Agaricus bisporus after harvest is a troublesome problem due to the lack of natural barriers that protect the cells. Higher humidity can cause water vapor condensation, which changes the color of mushrooms. The color determines the choice of consumers when buying mushrooms. Other features important for consumers are the size of the cap and firmness [5]. To prolong the shelf life of fresh button mushrooms without compromising the nutritional value, enzymatic, physical, and biochemical processes that occur during storage should be delayed [6]. 
Recently, ozone has been used to reduce decay and extend the storage period of produce [7]. Ozone is an allotropic form of oxygen consisting of three-atomic molecules. It is a natural agent and has high aseptic properties, therefore it is used in water disinfection. Ozone, due to an antimicrobial attribute, together with its potential of oxidation, is an effective choice to use on food [8]. In food production, ozone has been used to inactivate microflora [9]. Onopiuk et al. [10], Escriche et al. [11], Salu et al. [9], and Onopiuk et al. [12] have confirmed that treating vegetables and fruits with ozone increases shelf life and reduces product decay. Application ozone to the food preservation industry is attractive due to the lack of environmentally harmful residues [13]. Ozone technology is a large application option because it is a very safe, neutral for health, and an environmentally friendly disinfection method; it can be an alternative technique in storage technology. Currently, ozone is probably an alternative option to chlorine and hydrogen peroxide in food applications [10]. The adaptation of ozone as an anti-bacterial agent that prolongs the shelf life and may reduce the usage of conventional chemical compounds that are negative to natural environment, e.g., chloride [10]. Ozone is strongly fungicidal and anti-bacterial and is also used for removal of pesticides, herbicides, and other residues [14]. Ozone does not affect the taste of food and leaves no detectable residues in the products treated with it [15]. Nevertheless, mushrooms are the most influenced by the disadvantaged results of ozone due to their phenolic compounds and moisture content [16,17]. Accordingly, an optimization of the conditions for ozonization must be investigated for each type of food.

The objective of our study was to apply an original method of prolonging the shelf life of Agaricus bisporus with the use of gaseous ozone. In this study, the effect of ozone dose, time of exposure, and storage time on selected physicochemical properties (weight loss, color, texture, total antioxidant activity, and total phenols) of Agaricus bisporus stored for 14 days in $2{ }^{\circ} \mathrm{C}$ was investigated.

\section{Materials and Methods}

\subsection{Plant Material}

Fresh Agaricus bisporus were bought after harvest from a farm of mushrooms (Grala Dabrowizna, Poland). Mushrooms were chosen in accordance with appearance and based on cap size of 50 to $60 \mathrm{~mm}$, a lack of the injure and visible infections, and with a maturity index of stage 1 in which the veil is tightly intact and cap is closed. Then, they were transported to the laboratory of Department of Technique and Food Development in $2 \mathrm{~h}$ at $8 \pm 1{ }^{\circ} \mathrm{C}$.

\subsection{Treatments}

After transportation, mushrooms were divided into seven groups: the first group was a control sample and other groups were located in the cooling room where gas ozone was supplied. To produce gas ozone, an ozone generator was used (Korona 02/10, Warsaw, Poland). Ozone was generated with the capacity of $13 \mathrm{~g} / \mathrm{h}$. The measuring head (GDX-70, Alter S.A., Tarnowo Podgórne, Poland) was used to measure the level of the generated ozone with the measurement range $0-5 \mathrm{mg} \mathrm{L}^{-1}$. Mushrooms were exposed to ozone with increasing concentration $0.5,1.0$ and $2.0 \mathrm{mg} \mathrm{L}^{-1}$ and applied two times with ozonization: 30 and $60 \mathrm{~min}$. The cooling chamber was held at $8{ }^{\circ} \mathrm{C}, 80 \%$ relative humidity (RH); temperature and $\mathrm{RH}$ were monitored during all experiments.

After ozonization, mushrooms were placed in PET boxes (app. $300 \mathrm{~g}$ in each package) and overwrapping with PVC (polyvinyl chloride). For each treatment, three replicates were performed. The following quality parameters: weight loss, color, and firmness were determined at $0,4,7,11$, and 14 days of storage at $2{ }^{\circ} \mathrm{C}$ and $80 \%$ relative humidity $(\mathrm{RH})$. Chemical parameters (total phenolic content and total antioxidant activity) were determined at 0,7 , and 14 days of storage. 


\subsection{Weight Loss}

The weight of the mushrooms was measured using RADWAG PS 6000/C/1 electronic balance (Radom, Poland).

The weight loss was calculated in accordance with Equation (1) [18]:

$$
\mathrm{WL}=\left(\mathrm{W}_{0}-\mathrm{W}_{\mathrm{S}}\right) / \mathrm{W}_{0} \times 100 \%
$$

where $\mathrm{WL}$-weight loss $(\mathrm{g} / 100 \mathrm{~g}), \mathrm{W}_{0}$-weight $(\mathrm{g})$ of day 0 , and $\mathrm{W}_{\mathrm{s}}$-weight $(\mathrm{g})$ of mushrooms at the end of storage time.

\subsection{Color Measurements}

The color of mushrooms was measured using a chromameter in $\mathrm{L}^{*} \mathrm{a}^{*} \mathrm{~b}^{*}$ system and illuminant D65, $2^{\circ}$ standard observer (Konica Minolta CR-400, Tokyo, Japan). The diameter of the measuring head was $8 \mathrm{~mm}$. The chromameter was calibrated on a white standard tile $\left(L^{*}=98.45, a^{*}=-0.10, b^{*}=-0.13\right)$. In this system, $L^{*}$ showed lightness (high values) and darkness (low values), $+a^{*}$ redness, $-a^{*}$ greenness, $+b^{*}$ yellowness, and $-b^{*}$ blueness $[19,20]$. At each storage time, external and internal color parameters $\left(L^{*}, a^{*}\right.$ and $\left.b^{*}\right)$ were measured. Ten measurements were performed at random locations on the caps of the mushrooms (external color parameters) and at the joint of the cap and the stipe (internal color parameters) and compared to values of the ideal mushroom color $-L^{*}=97, a^{*}=-2$, $\mathrm{b}=0$ - using $\Delta \mathrm{E}$ as described by the Equation (2) [21]:

$$
\Delta \mathrm{E}=\left[\left(\mathrm{L}^{*}-97\right)^{2}+\left(\mathrm{a}^{*}-(-2)\right)^{2}+\mathrm{b}^{* 2}\right]^{1 / 2}
$$

where: $\Delta \mathrm{E}$ shows the degree of overall color change.

The browning index (BI), which represents the purity of brown color [22], was calculated, according to Equation (3)

$$
\mathrm{BI}=100 \times(\mathrm{x}-0.31) / 0.172
$$

where $\mathrm{x}=\left(\mathrm{a}^{*}+1.75 \mathrm{~L}^{*}\right) /\left(5.645 \mathrm{~L}^{*}+\mathrm{a}^{*}-3.012 \mathrm{~b}^{*}\right)$

\subsection{Texture Measurement}

Firmness of mushroom was defined by a TPA test (texture profile analysis) using Universal Testing Machine Instron 5965 (Instron, Norwood, MA, USA). For compression, a cylinder probe of $4 \mathrm{~cm}$ diameter was used. Uniform cylindrical disks $(10 \mathrm{~mm}$ high and $12 \mathrm{~mm}$ in diameter) were cut from the cap (3 disks per mushroom). Compression was set to $50 \%$ of original disk height and with constant contact area. Measurements were performed on ten mushroom caps for each treatment. Firmness was calculated from the force versus time curve: firmness was the force required to achieve a defined deformation. The compression force was measured at the maximum peak of the recorded force in Newtons $(\mathrm{N})$.

\subsection{Total Phenolic Content (TPC)}

Total phenolic content (TPC) was set according to the method of Dubost et al. (2007), with modifications [18]. In brief, mushroom powder (5 g dry) was extracted with ethanol $(80 \%)$ for $60 \mathrm{~min}$ and mixed in IKA MS 3 (Taufkirchen, Germany) at $175 \mathrm{rpm}$. Extraction was performed in triplicate. The next extract was centrifuged $(3755 \times g)(\mathrm{MPW}-251$,MED. INSTRUMENTS, Warsaw, Poland) for $20 \mathrm{~min}$ and the supernatant was collected. Then, $0.8 \mathrm{~mL}$ of $10 \%$ Folin-Ciocalteu reagent was added to the $0.2 \mathrm{~mL}$ ethanol extract. An amount of $1.25 \mathrm{~mL}$ of $7 \%$ sodium carbonate solution was added and mixed after $3 \mathrm{~min}$. The mixture was placed at $40{ }^{\circ} \mathrm{C}$ for $60 \mathrm{~min}$ in a water bath (WNB 7 Memmert, Schwabach, Germany). Absorbance was measured spectrophotometrically at the wavelength of $576 \mathrm{~nm}$ using Tecan Spark ${ }^{\mathrm{TM}}$ (10M, Männedorf, Switzerland). TPC was expressed in mg of gallic acid 
equivalents (GAE) per g of dry mushroom extract (mg GAE/g). All solvents and reagents were purchased from Sigma Company (Sigma Aldrich Inc., St. Louis, MO, USA).

\subsection{Total Antioxidant Activity (TAA)}

Anti-radical activity of the Agaricus bisporus was determined as a reductive ability applied to 2,2-Diphenyl-1-picrylhydrazyl (DPPH), according to the method of Choi et al. [23]. Mushroom extract $(0.2 \mathrm{~mL})$ (the method of preparation is presented in Section 2.6) was mixed for $30 \mathrm{sec}$. with $0.8 \mathrm{~mL}$ of DPPH solution and was placed for $15 \mathrm{~min}$ at $20^{\circ} \mathrm{C}$ in darkness. The absorbance was measured at the wave lengths of $517 \mathrm{~nm}$ (Tecan Spark TM $10 \mathrm{M}$, Männedorf, Switzerland). As a control solution, ethanol (80\%) was used. All solvents and reagents were purchased from Sigma Company (Sigma Aldrich Inc., St. Louis, MO, USA). The total antioxidant activity (TAA) was expressed as percent of reduction of DPPH calculated from Equation (4):

$$
\operatorname{TTA}(\%)=\left(1-\mathrm{Abs}_{\text {sample }} / \mathrm{Abs}_{\text {control }}\right) \times 100 \%
$$

where $\mathrm{Abs}_{\text {sample }}$ - $\mathrm{absorbance}$ of the sample and $\mathrm{Abs}_{\text {control }}$-absorbance of the control (without the mushroom extract). All analyses were performed in triplicate.

\subsection{Statistical Analysis}

The measurements were subjected to analysis of variance (ANOVA) using Statistica 12.5 (StatSoft Inc., Tulsa, OK, USA) in order to define the effect of ozone concentration and storage time on each variable. The differences between treatments groups were studied according to Tukey's test, performed at the significant level of $p \leq 0.05$. Results were shown as mean values and standard error.

\section{Results and Discussion}

The use of various concentrations of ozone dose, time of ozonization, and extension of storage time of mushrooms can have a significant impact on its physicochemical properties. The data presented in Table 1 show a significant effect $(p<0.001)$ of storage period on all measured parameters except TPC, in which the significant effect is $p<0.01$. The interactions between the storage time and the ozone dose as well as between the storage time and ozone dose and the time of ozonation were also indicated for all the tested parameters. There was no effect of ozonation time on the measured chemical parameters (TPC and TAA). The ozone dose and the ozonation time also had a smaller effect on weight loss $(p<0.05)$. There was no interaction between ozone dose and ozonation time for weight loss.

Table 1. Test probabilities for physicochemical characteristics, in general, depending on storage period, ozone dose, and time of ozonization-multi-aspect variance analysis including interactions.

\begin{tabular}{|c|c|c|c|c|c|c|c|}
\hline \multirow[b]{2}{*}{ Item } & \multicolumn{3}{|c|}{ Effect } & \multicolumn{4}{|c|}{ Interaction } \\
\hline & $\begin{array}{l}\text { Storage Period } \\
\text { (day) SP }\end{array}$ & $\begin{array}{c}\text { Ozone Dose } \\
\text { (ml/L) OD }\end{array}$ & $\begin{array}{c}\text { Time of } \\
\text { Ozonization } \\
\text { (min) OT }\end{array}$ & $\mathbf{S P} \times \mathbf{O D}$ & $\mathrm{SP} \times \mathrm{OT}$ & $\mathrm{OD} \times \mathrm{OT}$ & $\mathrm{SP} \times \mathrm{OD} \times \mathrm{OT}$ \\
\hline Weight loss (\%) & $* * *$ & * & * & $* * *$ & $* * *$ & NS & $* * *$ \\
\hline firmness & $* * *$ & $* * *$ & $* * *$ & $* * *$ & $* * *$ & $* * *$ & $* * *$ \\
\hline$L^{*}$ external & $* * *$ & $* * *$ & $* * *$ & $* * *$ & $* * *$ & $* * *$ & $* * *$ \\
\hline$a^{*}$ external & $* * *$ & $* * *$ & $* * *$ & $* * *$ & $* * *$ & $* * *$ & $* * *$ \\
\hline $\mathrm{b}^{*}$ external & $* * *$ & $* * *$ & $* * *$ & $* * *$ & $* * *$ & $* * *$ & $* * *$ \\
\hline $\mathrm{L}^{*}$ internal & $* * *$ & $* * *$ & $* * *$ & $* * *$ & $* * *$ & $* * *$ & $* * *$ \\
\hline$a^{*}$ internal & $* * *$ & $* * *$ & $* * *$ & $* * *$ & $* * *$ & $* * *$ & $* * *$ \\
\hline $\mathrm{b}^{*}$ internal & $* * *$ & $* * *$ & $* *$ & $* * *$ & $* * *$ & $* * *$ & $* * *$ \\
\hline BI external & $* * *$ & $* * *$ & $* * *$ & $* * *$ & $* * *$ & $* * *$ & $* * *$ \\
\hline BI internal & $* * *$ & $* * *$ & $* * *$ & $* * *$ & $* * *$ & $* * *$ & $* * *$ \\
\hline$\Delta \mathrm{E}$ external & $* * *$ & $* * *$ & $* * *$ & $* * *$ & $* * *$ & $* * *$ & $* * *$ \\
\hline$\Delta \mathrm{E}$ internal & $* * *$ & $* * *$ & $* * *$ & $* * *$ & $* * *$ & $* * *$ & $* * *$ \\
\hline TAA & $* * *$ & $* * *$ & NS & $* * *$ & $* * *$ & $* * *$ & $* * *$ \\
\hline TPC & $* *$ & ** & NS & $* * *$ & NS & $* * *$ & $* * *$ \\
\hline
\end{tabular}

${ }^{*} p<0.05 ;{ }^{* *} p<0.01,{ }^{* * *} p<0.001$, NS: not significant. 


\subsection{Assessment of Mushrooms Weight Loss during Storage}

Table 2 shows the weight loss of ozonized button mushrooms measured at the end of storage periods for samples stored for 14 days at $2{ }^{\circ} \mathrm{C}$. The weight loss increased with the ozone dose and the storage time for all mushroom samples. The lowest weight loss was observed for the control sample and for the sample ozonized for $60 \mathrm{~min}$ with $0.5 \mathrm{mg} / \mathrm{L}$ concentration on the 14th day of storage. The time of ozonization of $60 \mathrm{~min}$ was allowed to reduce the loss of mass compared to the samples ozonized for $30 \mathrm{~min}$. The greatest weight loss was recorded for the sample ozonized for $30 \mathrm{~min}$ at the concentration of $2 \mathrm{mg} / \mathrm{L}$ on the 14th day of storage. Along with an increase in ozone concentration, greater weight losses were found on each day of storage. According to Zhang et al. [24], visible wilting and wrinkling of most vegetables and fruits was seen in water loss of above $4-6 \%$ of the whole fresh weight. In this study, weight loss was up to $1.5 \%$ in all samples. The mushroom storage losses referred to storage conditions and ripening processes. Despite the weight loss of Agaricus bisporus identified in this study, the use of gaseous ozone should not be resigned in order to prolong the shelf life, for example, mushrooms. Ozonization is an ecological technique of food preservation, and it does not cause additional pollution, as ozone contact with solid materials causes decomposition into molecular oxygen.

Table 2. Impact of ozone dose, time of ozonization, and storage time on weight loss (WL) (\%) of Agaricus bisporus measured on $4,7,11$, and 14 days of storage at $2{ }^{\circ} \mathrm{C}$.

\begin{tabular}{|c|c|c|}
\hline Group & Days of Storage & WL (\%) \\
\hline \multirow{4}{*}{ Control } & 4 & $0.17^{\mathrm{aA}} \pm 0.02$ \\
\hline & 7 & $0.43^{\mathrm{bA}} \pm 0.03$ \\
\hline & 11 & $0.53^{\mathrm{bA}} \pm 0.02$ \\
\hline & 14 & $0.91^{\mathrm{cA}} \pm 0.02$ \\
\hline \multirow{4}{*}{$0.5 \mathrm{mg} \mathrm{L}^{-1} ; 30 \mathrm{~min}$} & 4 & $0.48^{\mathrm{aB}} \pm 0.03$ \\
\hline & 7 & $0.58^{\mathrm{aB}} \pm 0.06$ \\
\hline & 11 & $0.73^{\mathrm{bB}} \pm 0.02$ \\
\hline & 14 & $1.06^{\mathrm{cB}} \pm 0.07$ \\
\hline \multirow{4}{*}{$0.5 \mathrm{mg} \mathrm{L}^{-1} ; 60 \mathrm{~min}$} & 4 & $0.58^{\mathrm{aB}} \pm 0.02$ \\
\hline & 7 & $0.78^{b C} \pm 0.03$ \\
\hline & 11 & $0.96^{\mathrm{cC}} \pm 0.05$ \\
\hline & 14 & $1.08^{\mathrm{cAB}} \pm 0.02$ \\
\hline \multirow{4}{*}{$1.0 \mathrm{mg} \mathrm{L}^{-1} ; 30 \mathrm{~min}$} & 4 & $0.75^{\mathrm{aC}} \pm 0.05$ \\
\hline & 7 & $0.77^{\mathrm{aCD}} \pm 0.03$ \\
\hline & 11 & $0.95^{\mathrm{bC}} \pm 0.06$ \\
\hline & 14 & $1.27^{\mathrm{cC}} \pm 0.05$ \\
\hline \multirow{4}{*}{$1.0 \mathrm{mg} \mathrm{L}^{-1} ; 60 \mathrm{~min}$} & 4 & $0.79^{\mathrm{aC}} \pm 0.03$ \\
\hline & 7 & $0.79^{\mathrm{aCD}} \pm 0.04$ \\
\hline & 11 & $0.94^{\mathrm{bC}} \pm 0.06$ \\
\hline & 14 & $1.19^{\mathrm{bC}} \pm 0.03$ \\
\hline \multirow{4}{*}{$2.0 \mathrm{mg} \mathrm{L}^{-1} ; 30 \mathrm{~min}$} & 4 & $0.86^{\mathrm{aC}} \pm 0.07$ \\
\hline & 7 & $0.84^{\mathrm{aCD}} \pm 0.04$ \\
\hline & 11 & $0.94^{\mathrm{aC}} \pm 0.03$ \\
\hline & 14 & $1.45^{\mathrm{bd}} \pm 0.07$ \\
\hline \multirow{4}{*}{$2.0 \mathrm{mg} \mathrm{L}^{-1} ; 60 \mathrm{~min}$} & 4 & $0.83^{\mathrm{aC}} \pm 0.04$ \\
\hline & 7 & $0.83^{\mathrm{aCD}} \pm 0.03$ \\
\hline & 11 & $0.97^{b C} \pm 0.03$ \\
\hline & 14 & $1.18^{\mathrm{cBC}} \pm 0.07$ \\
\hline
\end{tabular}


Results presented in our study agreed with studies conducted by de Souza et al. [17], in which there was a small increase in the percentage of weight loss of carrots in all treatments, with no difference between carrots nontreated and treated ozone. The effect of ozone on weight loss was studied in several fruits and vegetables with varying results. Concentration of ozone $(2.8-9.3 \mu \mathrm{g} / \mathrm{L})$ had a small effect on the weight loss of papaya fruit treated for 4 days [25]. Palou et al. [26] observed in "Zee Lady" peaches that low-level ozone treatment was unaffected in the reduction of weight loss but increased when exposed to higher concentrations of ozone.

Many studies suggested that for different products, there is a threshold value in ozone dose above which the exposure may cause injury to the product [17]. It has been implied that higher concentrations of ozone may result in injury to the cuticle or epidermal tissues [26]. In this study, a weight loss of approx. 1\% was observed for the samples ozonized with the lowest dose of $0.5 \mathrm{mg} / \mathrm{L}$, regardless of the time of ozonization. All weight loss noted in this study were due to the 14-day shelf life instead of the application of the ozone. According to Escriche et al. [11], weight loss relates to postharvest respiratory phenomena that requires a suitable substrate. In mushrooms, these substrates are mannitol, trehalose, and glycogen.

\subsection{Color Measurements}

The color of mushrooms, fruits, and vegetables is important because any changes in appearance may be reflected as a symptom of deterioration [27]. In this study, the color in the $\mathrm{L}^{*} \mathrm{a}^{*} \mathrm{~b}^{*}$ system of Agaricus bisporus is presented in Tables 3 and 4 . The changes in the color were controlled by measuring $\mathrm{L}^{*}, \mathrm{a}^{*}, \mathrm{~b}^{*}, \Delta \mathrm{E}$, and BI. A decrease in storage time of external and internal $\mathrm{L}^{*}$ parameters was observed but the rate of decline of the external $\mathrm{L}^{*}$ parameter was greater than that of the internal $\mathrm{L}^{*}$ parameter. Therefore, the browning index (BI) increased with the storage time for all treatments. The values of internal BI for ozonized mushrooms compared to external BI values may indicate that the ozone did not penetrate into the fungal tissue. Time of storage is an important element in color deterioration of mushrooms. The highest external $\mathrm{L}^{*}$ parameter $(83.15 \pm 2.23)$ and the lowest $\Delta \mathrm{E}(21.52 \pm 2.58)$ were observed for control group after 14 days of storage. For all ozonized groups, external $L^{*}$ and $\Delta E$ parameters were statistically significantly $(p<0.05)$ and decreased and increased, respectively, during storage. The highest values of internal $\mathrm{L}^{*}$ parameters were noticed for groups ozonized with $1 \mathrm{mg} / \mathrm{L}$ for $60 \mathrm{~min}$ and with $2 \mathrm{mg} / \mathrm{L}$ for $30 \mathrm{~min}(89.74 \pm 2.06$ and $91.76 \pm 1.73$, respectively). With storage time and ozone concentration, mushrooms became more yellow (increase in the value of $b^{*}$ parameter). In our study, an increase of external and internal $b^{*}$ values after 14 days in all groups was observed. The internal $\mathrm{L}^{*}$ parameter after 14 days of storage for all ozonized group was above 80 , which is connected to satisfactory lightness for consumers. Zalewska et al. [20] demonstrated that mushrooms with an external $\mathrm{L}^{*}$ value higher than 86 can be categorized as good quality and for external L* values between 85 and 80 as fair quality. In this study, after 14 days of storage, internal $\mathrm{L}^{*}$ values of mushrooms were still considered as good quality. As expected, $\Delta \mathrm{E}$ increased $(p<0.05)$ during storage time. Browning of mushrooms is an important factor in loss of postharvest quality during storage. Oxidation of phenol compounds may cause forming of browning complexes [28]. Depending on the values of $\mathrm{L}^{*}, \mathrm{a}^{*}$, and $\mathrm{b}^{*}$ color parameters, the browning index (BI) increased with storage time in all treatments $(p<0.05)$. Increased values of BI were associated with a generalized enzymatic browning in mushrooms during storage.

Skog and Chu [7] informed that after 14 days of storage at $4{ }^{\circ} \mathrm{C}$, ozone-treated mushrooms had lower $\mathrm{L}^{*}$ parameters than initially and the BI was higher than in the control mushrooms. Escriche et al. [11] also noticed a decrease in external and internal lightness after 7 days of storage in mushrooms ozonized for 15 and $30 \mathrm{~min}$. Andrés et al. [28] and Oliveira et al. [29] also found that Agaricus bisporus with storage time lost their luminosity and turned brown with a decline in $L^{*}$ and became yellow with a rise in $b^{*}$. 
Table 3. Effect of ozone dose, time of ozonization, and storage time on the external color parameters of the Agaricus bisporus measured at $0,4,7,11$, and 14 days of storage.

\begin{tabular}{|c|c|c|c|c|c|c|c|}
\hline & \multirow{2}{*}{\multicolumn{2}{|c|}{ Group }} & \multicolumn{5}{|c|}{ Storage Period (days) } \\
\hline & & & 0 & 4 & 7 & 11 & 14 \\
\hline \multirow{4}{*}{$L^{*}(\%)$} & \multicolumn{2}{|c|}{ Control } & $94.31^{c} \pm 0.74$ & $92.12^{b c} \pm 0.88$ & $89.55^{a} \pm 1.42$ & $85.39^{a} \pm 2.76$ & $83.15^{\mathrm{aB}} \pm 2.23$ \\
\hline & $0.5 \mathrm{mg} / \mathrm{L}$ & $\begin{array}{l}30 \min \\
60 \min \end{array}$ & $\begin{array}{l}94.31^{c} \pm 0.74 \\
94.31^{c} \pm 0.74\end{array}$ & $\begin{array}{c}75.86^{\mathrm{bBC}} \pm 3.43 \\
75.72^{\mathrm{bB}} \pm 2.84\end{array}$ & $\begin{array}{c}68.54^{\mathrm{aA}} \pm 3.21 \\
71.71^{\mathrm{aBC}} \pm 1.48\end{array}$ & $\begin{array}{l}69.86^{\mathrm{aAB}} \pm 1.58 \\
72.96^{\mathrm{abC}} \pm 1.23\end{array}$ & $\begin{array}{l}69.29^{\mathrm{aA}} \pm 1.55 \\
70.28^{\mathrm{aA}} \pm 1.27\end{array}$ \\
\hline & $1 \mathrm{mg} / \mathrm{L}$ & $\begin{array}{l}30 \mathrm{~min} \\
60 \mathrm{~min}\end{array}$ & $\begin{array}{l}94.31^{\mathrm{c}} \pm 0.74 \\
94.31^{\mathrm{d}} \pm 0.74\end{array}$ & $\begin{array}{c}73.81^{\mathrm{bAB}} \pm 2.37 \\
75.76^{\mathrm{cB}} \pm 2.25\end{array}$ & $\begin{array}{l}71.95^{\mathrm{abC}} \pm 1.44 \\
69.02^{\mathrm{aAB}} \pm 2.04\end{array}$ & $\begin{array}{c}72.32^{\mathrm{abBC}} \pm 1.03 \\
72.36^{\mathrm{bBC}} \pm 1.32\end{array}$ & $\begin{array}{l}70.49^{\mathrm{aA}} \pm 1.10 \\
68.09^{\mathrm{aA}} \pm 1.79\end{array}$ \\
\hline & $2 \mathrm{mg} / \mathrm{L}$ & $\begin{array}{l}30 \mathrm{~min} \\
60 \mathrm{~min}\end{array}$ & $\begin{array}{l}94.31^{\mathrm{c}} \pm 0.74 \\
94.31^{\mathrm{c}} \pm 0.74\end{array}$ & $\begin{array}{l}78.74^{\mathrm{bC}} \pm 1.76 \\
72.65^{\mathrm{bA}} \pm 2.35\end{array}$ & $\begin{array}{l}73.41^{\mathrm{aC}} \pm 1.35 \\
73.88^{\mathrm{bC}} \pm 1.38\end{array}$ & $\begin{array}{l}72.93^{\mathrm{aC}} \pm 1.10 \\
68.01^{\mathrm{aA}} \pm 1.63\end{array}$ & $\begin{array}{l}70.70^{\mathrm{aA}} \pm 1.15 \\
68.46^{\mathrm{aA}} \pm 1.40\end{array}$ \\
\hline \multirow{4}{*}{$\mathrm{a}^{*}(-)$} & \multicolumn{2}{|c|}{ Control } & $-0.66^{\mathrm{a}} \pm 0.10$ & $-0.03^{\mathrm{aA}} \pm 0.39$ & $1.17^{\mathrm{bA}} \pm 0.42$ & $2.39^{\mathrm{cA}} \pm 0.76$ & $2.93^{\mathrm{cA}} \pm 0.62$ \\
\hline & $0.5 \mathrm{mg} / \mathrm{L}$ & $\begin{array}{l}30 \mathrm{~min} \\
60 \mathrm{~min}\end{array}$ & $\begin{array}{l}-0.66^{\mathrm{a}} \pm 0.10 \\
-0.66^{\mathrm{a}} \pm 0.10\end{array}$ & $\begin{array}{l}5.67^{\mathrm{bCD}} \pm 1.49 \\
5.81^{\mathrm{bCD}} \pm 0.94\end{array}$ & $\begin{array}{l}7.59^{\mathrm{cC}} \pm 1.19 \\
6.88^{\mathrm{bC}} \pm 0.81\end{array}$ & $\begin{array}{c}7.28^{\mathrm{cE}} \pm 0.68 \\
6.16^{\mathrm{bCDE}} \pm 0.49\end{array}$ & $\begin{array}{c}6.67^{\mathrm{bcB}} \pm 0.72 \\
6.25^{\mathrm{bB}} \pm 0.82\end{array}$ \\
\hline & $1 \mathrm{mg} / \mathrm{L}$ & $\begin{array}{l}30 \mathrm{~min} \\
60 \mathrm{~min}\end{array}$ & $\begin{array}{l}-0.66^{\mathrm{a}} \pm 0.10 \\
-0.66^{\mathrm{a}} \pm 0.10\end{array}$ & $\begin{array}{l}6.58^{\mathrm{bD}} \pm 0.67 \\
5.38^{\mathrm{bC}} \pm 1.19\end{array}$ & $\begin{array}{l}6.77^{\mathrm{bC}} \pm 0.55 \\
6.77^{\mathrm{cC}} \pm 0.62\end{array}$ & $\begin{array}{c}6.03^{\mathrm{bBCD}} \pm 0.63 \\
4.95^{\mathrm{bB}} \pm 0.47\end{array}$ & $\begin{array}{c}6.38^{\mathrm{bB}} \pm 0.82 \\
5.80^{\mathrm{bcB}} \pm 0.64\end{array}$ \\
\hline & $2 \mathrm{mg} / \mathrm{L}$ & $\begin{array}{l}30 \mathrm{~min} \\
60 \mathrm{~min}\end{array}$ & $\begin{array}{l}-0.66^{\mathrm{a}} \pm 0.10 \\
-0.66^{\mathrm{a}} \pm 0.10\end{array}$ & $\begin{array}{c}4.10^{\mathrm{bB}} \pm 0.99 \\
6.38^{\mathrm{cCD}} \pm 0.78\end{array}$ & $\begin{array}{l}5.43^{\mathrm{cB}} \pm 0.46 \\
4.85^{\mathrm{bB}} \pm 0.77\end{array}$ & $\begin{array}{c}5.13^{\mathrm{bcBC}} \pm 0.33 \\
6.48^{\mathrm{cDE}} \pm 0.94\end{array}$ & $\begin{array}{l}6.01^{\mathrm{cB}} \pm 0.51 \\
6.71^{\mathrm{CB}} \pm 0.76\end{array}$ \\
\hline \multirow{4}{*}{$b^{*}(-)$} & \multicolumn{2}{|c|}{ Control } & $8.48^{a} \pm 0.25$ & $12.71^{\mathrm{bA}} \pm 1.37$ & $14.05^{\mathrm{bcA}} \pm 0.66$ & $14.58^{\mathrm{bcA}} \pm 1.35$ & $15.67^{\mathrm{cA}} \pm 1.70$ \\
\hline & $0.5 \mathrm{mg} / \mathrm{L}$ & $\begin{array}{l}30 \min \\
60 \min \end{array}$ & $\begin{array}{l}8.48^{a} \pm 0.25 \\
8.48^{a} \pm 0.25\end{array}$ & $\begin{array}{l}18.44^{\mathrm{bBC}} \pm 3.18 \\
18.74^{\mathrm{bBC}} \pm 1.27\end{array}$ & $\begin{array}{c}22.12^{\mathrm{cC}} \pm 2.56 \\
20.78^{\mathrm{bBC}} \pm 1.42\end{array}$ & $\begin{array}{c}23.41^{\mathrm{cC}} \pm 1.86 \\
21.09^{\mathrm{bBC}} \pm 1.26\end{array}$ & $\begin{array}{l}21.02^{\mathrm{cBC}} \pm 2.06 \\
20.70^{\mathrm{bBC}} \pm 1.46\end{array}$ \\
\hline & $1 \mathrm{mg} / \mathrm{L}$ & $\begin{array}{l}30 \mathrm{~min} \\
60 \mathrm{~min}\end{array}$ & $\begin{array}{l}8.48^{a} \pm 0.25 \\
8.48^{a} \pm 0.25\end{array}$ & $\begin{array}{c}20.44^{\mathrm{bC}} \pm 1.12 \\
18.33^{\mathrm{bBC}} \pm 1.87\end{array}$ & $\begin{array}{l}22.45^{\mathrm{bcC}} \pm 1.55 \\
21.03^{\mathrm{cBC}} \pm 1.44\end{array}$ & $\begin{array}{c}21.23 \mathrm{bcBC} \pm 1.08 \\
19.45^{\mathrm{bcB}} \pm 1.07\end{array}$ & $\begin{array}{c}23.01^{\mathrm{cC}} \pm 1.73 \\
19.26^{\mathrm{bcB}} \pm 1.14\end{array}$ \\
\hline & $2 \mathrm{mg} / \mathrm{L}$ & $\begin{array}{l}30 \mathrm{~min} \\
60 \mathrm{~min}\end{array}$ & $\begin{array}{l}8.48^{\mathrm{a}} \pm 0.25 \\
8.48^{\mathrm{a}} \pm 0.25\end{array}$ & $\begin{array}{c}16.61^{\mathrm{bB}} \pm 1.69 \\
20.24^{\mathrm{bcC}} \pm 1.20\end{array}$ & $\begin{array}{l}19.33^{\mathrm{cB}} \pm 0.70 \\
18.70^{\mathrm{bB}} \pm 1.24\end{array}$ & $\begin{array}{c}18.97^{\mathrm{bcB}} \pm 0.90 \\
21.25^{\mathrm{cB}} \pm 1.40\end{array}$ & $\begin{array}{c}19.84^{\mathrm{CB}} \pm 1.00 \\
21.62^{\mathrm{CBC}} \pm 2.28\end{array}$ \\
\hline \multirow{4}{*}{$\Delta \mathrm{E}(-)$} & \multicolumn{2}{|c|}{ Control } & $9.02^{a} \pm 0.25$ & $13.78^{\mathrm{bA}} \pm 1.50$ & $16.25^{\mathrm{bcA}} \pm 1.24$ & $19.22^{\mathrm{cdA}} \pm 2.66$ & $21.52^{\mathrm{dA}} \pm 2.58$ \\
\hline & $0.5 \mathrm{mg} / \mathrm{L}$ & $\begin{array}{l}30 \mathrm{~min} \\
60 \mathrm{~min}\end{array}$ & $\begin{array}{l}9.02^{\mathrm{a}} \pm 0.25 \\
9.02^{\mathrm{a}} \pm 0.25\end{array}$ & $\begin{array}{c}29.10^{\mathrm{bC}} \pm 4.76 \\
29.44^{\mathrm{bCD}} \pm 2.86\end{array}$ & $\begin{array}{c}37.35^{\mathrm{cE}} \pm 3.78 \\
33.94^{\mathrm{cCD}} \pm 1.72 \\
\end{array}$ & $\begin{array}{l}37.05^{\mathrm{cC}} \pm 2.02 \\
33.02^{\mathrm{cB}} \pm 1.59\end{array}$ & $\begin{array}{l}35.88^{\mathrm{cB}} \pm 2.17 \\
34.81^{\mathrm{cB}} \pm 1.76\end{array}$ \\
\hline & $1 \mathrm{mg} / \mathrm{L}$ & $\begin{array}{l}30 \min \\
60 \min \end{array}$ & $\begin{array}{l}9.02^{\mathrm{a}} \pm 0.25 \\
9.02^{\mathrm{a}} \pm 0.25\end{array}$ & $\begin{array}{c}32.11^{b C D} \pm 2.32 \\
29.03^{b C} \pm 2.87\end{array}$ & $\begin{array}{c}34.79 \mathrm{bcCDE} \pm 1.63 \\
36.12 \mathrm{cDE} \pm 1.94\end{array}$ & $\begin{array}{c}33.54^{\mathrm{bcB}} \pm 1.29 \\
32.16^{\mathrm{bB}} \pm 1.56\end{array}$ & $\begin{array}{l}36.12^{\mathrm{cB}} \pm 1.36 \\
35.62^{\mathrm{cB}} \pm 1.82\end{array}$ \\
\hline & $2 \mathrm{mg} / \mathrm{L}$ & $\begin{array}{l}30 \mathrm{~min} \\
60 \mathrm{~min}\end{array}$ & $\begin{array}{l}9.02^{\mathrm{a}} \pm 0.25 \\
9.02^{\mathrm{a}} \pm 0.25\end{array}$ & $\begin{array}{l}25.44^{\mathrm{bB}} \pm 2.49 \\
32.78^{\mathrm{bD}} \pm 2.45\end{array}$ & $\begin{array}{c}31.41^{\mathrm{cBC}} \pm 1.30 \\
30.53^{\mathrm{bB}} \pm 1.82\end{array}$ & $\begin{array}{l}31.47^{\mathrm{cB}} \pm 1.38 \\
36.95^{\mathrm{CC}} \pm 2.01\end{array}$ & $\begin{array}{l}33.91^{\mathrm{cB}} \pm 1.47 \\
36.90^{\mathrm{cB}} \pm 1.92\end{array}$ \\
\hline \multirow{4}{*}{$\mathrm{BI}(-)$} & \multicolumn{2}{|c|}{ Control } & $8.57^{a} \pm 0.26$ & $14.33^{\mathrm{bA}} \pm 1.80$ & $17.47^{\mathrm{bcA}} \pm 1.41$ & $20.25^{\mathrm{bcA}} \pm 2.99$ & $22.89^{\mathrm{cA}} \pm 3.47$ \\
\hline & $0.5 \mathrm{mg} / \mathrm{L}$ & $\begin{array}{l}30 \mathrm{~min} \\
60 \mathrm{~min}\end{array}$ & $\begin{array}{l}8.57^{a} \pm 0.26 \\
8.57^{a} \pm 0.26\end{array}$ & $\begin{array}{l}32.96^{\mathrm{bBC}} \pm 7.72 \\
33.35^{\mathrm{bBC}} \pm 4.24\end{array}$ & $\begin{array}{c}46.41^{\mathrm{CD}} \pm 8.76 \\
40.29^{\mathrm{cCD}} \pm 3.79\end{array}$ & $\begin{array}{c}47.34^{\mathrm{cD}} \pm 5.09 \\
39.34^{\mathrm{bcBC}} \pm 3.28\end{array}$ & $\begin{array}{l}42.27^{\mathrm{CBC}} \pm 5.53 \\
40.44^{\mathrm{CBC}} \pm 4.14\end{array}$ \\
\hline & $1 \mathrm{mg} / \mathrm{L}$ & $\begin{array}{l}30 \mathrm{~min} \\
60 \mathrm{~min}\end{array}$ & $\begin{array}{l}8.57^{\mathrm{a}} \pm 0.26 \\
8.57^{\mathrm{a}} \pm 0.26 \\
\end{array}$ & $\begin{array}{c}38.10^{\mathrm{bC}} \pm 3.60 \\
32.22^{\mathrm{bBC}} \pm 4.98\end{array}$ & $\begin{array}{c}43.24^{\mathrm{bcD}} \pm 3.88 \\
42.54^{\mathrm{cD}} \pm 3.86\end{array}$ & $\begin{array}{c}39.84^{\mathrm{bcBC}} \pm 2.89 \\
35.42^{\mathrm{bB}} \pm 2.90\end{array}$ & $\begin{array}{c}44.97^{\mathrm{cC}} \pm 4.11 \\
38.56^{\mathrm{bcBC}} \pm 3.28\end{array}$ \\
\hline & $2 \mathrm{mg} / \mathrm{L}$ & $\begin{array}{l}30 \mathrm{~min} \\
60 \mathrm{~min}\end{array}$ & $\begin{array}{l}8.57^{a} \pm 0.26 \\
8.57^{a} \pm 0.26\end{array}$ & $\begin{array}{c}26.87^{\mathrm{bB}} \pm 4.09 \\
38.25^{\mathrm{bcC}} \pm 3.88\end{array}$ & $\begin{array}{c}35.09^{\mathrm{cBC}} \pm 2.04 \\
33.18^{\mathrm{bB}} \pm 3.49\end{array}$ & $\begin{array}{c}34.41^{\mathrm{cB}} \pm 2.37 \\
43.45^{\mathrm{CCD}} \pm 4.58\end{array}$ & $\begin{array}{c}38.23^{\mathrm{CB}} \pm 2.88 \\
44.12^{\mathrm{CBC}} \pm 5.49\end{array}$ \\
\hline
\end{tabular}

a-d: significant statistical differences for each treatment during storage time $(p<0.05)$; ${ }^{\mathrm{A}-\mathrm{D}}$ : significant statistical differences between treatments within each storage time $(p<0.05)$. The values represent the mean \pm standard error.

With the measured color parameters, it can be concluded that the use of ozone on the external browning process accelerates during storage, while there is a delay in internal browning. The greater external browning may be caused by the layer covering the mushroom cap breaking during handling, combined with the polyphenol oxidase with oxygen, which then causes formation of a dark pigment that is responsible for color deterioration. The use of an additional barrier from external conditions, for example appropriate packaging, may stop the negative effects of processing, especially browning or yellowing. Wang et al. [30] applied ozone fumigation with nano-film packaging and delayed the browning, weight loss, reduced firmness, and deterioration of sensory quality. Based on the values of the internal color parameters after 14 days of storage, it can be concluded that the mushrooms still maintained good quality, especially for an ozone dose of $2 \mathrm{mg} / \mathrm{L}$ 
and an ozonization time of $30 \mathrm{~min}$. Wang et al. [30] found that the optimal dose of ozone should be $2.77 \mathrm{mg} / \mathrm{L}$ and time of ozonization should be $15 \mathrm{~min}$. In our work, a similar dose of ozone was used ( $2 \mathrm{mg} / \mathrm{L}$ vs. $2.77 \mathrm{mg} / \mathrm{L})$, but the ozonation time was extended twice. The reduction of the ozonation time in the work of Wang et al. [30] may be caused by the use of an additional barrier in the form of nano-packaging. The use of a special foil with nanoparticles maintains appropriate humidity and temperature conditions around the product. In their study, the shelf life of mushrooms was extended by 8-10 days. Hence, Agaricus bisporus maintains good quality and texture during storage and maintained a higher trading quality.

Table 4. Impact of ozone dose, time of ozonization, and storage time on the internal color parameters of the Agaricus bisporus measured at $0,4,7,11$, and 14 days of storage.

\begin{tabular}{|c|c|c|c|c|c|c|c|}
\hline & \multirow{2}{*}{\multicolumn{2}{|c|}{ Group }} & \multicolumn{5}{|c|}{ Storage Period (days) } \\
\hline & & & 0 & 4 & 7 & 11 & 14 \\
\hline \multirow{4}{*}{$\mathrm{L}^{*}(\%)$} & \multicolumn{2}{|c|}{ Control } & $91.92^{c} \pm 0.76$ & $90.64^{\mathrm{cAB}} \pm 1.20$ & $84.17^{\mathrm{bA}} \pm 2.62$ & $85.01^{\mathrm{bA}} \pm 2.60$ & $78.34^{\mathrm{aA}} \pm 1.70$ \\
\hline & $0.5 \mathrm{mg} / \mathrm{L}$ & $\begin{array}{l}30 \mathrm{~min} \\
60 \mathrm{~min}\end{array}$ & $\begin{array}{l}91.92^{b c} \pm 0.76 \\
91.92^{b} \pm 0.76\end{array}$ & $\begin{array}{c}89.61^{\mathrm{bAB}} \pm 1.80 \\
92.21^{\mathrm{bB}} \pm 1.11\end{array}$ & $\begin{array}{l}89.68^{\mathrm{bB}} \pm 1.46 \\
91.47^{\mathrm{bB}} \pm 3.25\end{array}$ & $\begin{array}{l}85.68^{\mathrm{aA}} \pm 1.90 \\
87.09^{\mathrm{aA}} \pm 2.46\end{array}$ & $\begin{array}{l}83.11^{\mathrm{aB}} \pm 1.03 \\
86.55^{\mathrm{aC}} \pm 1.53\end{array}$ \\
\hline & $1 \mathrm{mg} / \mathrm{L}$ & $\begin{array}{l}30 \mathrm{~min} \\
60 \mathrm{~min}\end{array}$ & $\begin{array}{l}91.92^{\mathrm{c}} \pm 0.76 \\
91.92^{\mathrm{b}} \pm 0.76\end{array}$ & $\begin{array}{c}88.55^{\mathrm{bA}} \pm 1.91 \\
89.81^{\mathrm{bAB}} \pm 1.76\end{array}$ & $\begin{array}{c}90.42^{\mathrm{bcB}} \pm 2.10 \\
83.95^{\mathrm{aA}} \pm 1.86\end{array}$ & $\begin{array}{c}91.34^{\mathrm{bcB}} \pm 0.89 \\
89.21^{\mathrm{bB}} \pm 1.91\end{array}$ & $\begin{array}{l}86.29^{\mathrm{aC}} \pm 1.19 \\
89.74^{\mathrm{bD}} \pm 2.06\end{array}$ \\
\hline & $2 \mathrm{mg} / \mathrm{L}$ & $\begin{array}{l}30 \mathrm{~min} \\
60 \mathrm{~min}\end{array}$ & $\begin{array}{c}91.92 \pm 0.76 \\
91.92^{\mathrm{b}} \pm 0.76\end{array}$ & $\begin{array}{c}89.46^{\mathrm{AB}} \pm 1.91 \\
90.54^{\mathrm{bAB}} \pm 2.24\end{array}$ & $\begin{array}{c}91.20^{\mathrm{B}} \pm 2.00 \\
89.60^{\mathrm{bB}} \pm 2.16\end{array}$ & $\begin{array}{c}90.13^{\mathrm{B}} \pm 2.45 \\
91.05^{\mathrm{bB}} \pm 2.03\end{array}$ & $\begin{array}{c}91.76^{\mathrm{DE}} \pm 1.73 \\
82.30^{\mathrm{aB}} \pm 2.3\end{array}$ \\
\hline \multirow{4}{*}{$a^{*}(-)$} & \multicolumn{2}{|c|}{ Control } & $-0.39^{a} \pm 0.12$ & $0.23^{\mathrm{aAB}} \pm 0.36$ & $2.22^{\mathrm{bD}} \pm 0.87$ & $1.53^{\mathrm{bD}} \pm 0.59$ & $3.12^{\mathrm{cC}} \pm 0.43$ \\
\hline & $0.5 \mathrm{mg} / \mathrm{L}$ & $\begin{array}{l}30 \mathrm{~min} \\
60 \mathrm{~min}\end{array}$ & $\begin{array}{l}-0.39^{\mathrm{ab}} \pm 0.12 \\
-0.39^{\mathrm{a}} \pm 0.12\end{array}$ & $\begin{array}{c}1.01^{\mathrm{cdB}} \pm 0.59 \\
-0.10^{\mathrm{abA}} \pm 0.43\end{array}$ & $\begin{array}{l}0.31^{\mathrm{bcBC}} \pm 0.53 \\
-0.64^{\mathrm{aA}} \pm 0.62\end{array}$ & $\begin{array}{l}1.38^{\mathrm{dCD}} \pm 0.44 \\
0.55^{\mathrm{bBC}} \pm 0.51\end{array}$ & $\begin{array}{c}-0.82^{\mathrm{aA}} \pm 0.16 \\
1.82^{\mathrm{cB}} \pm 0.93\end{array}$ \\
\hline & $1 \mathrm{mg} / \mathrm{L}$ & $\begin{array}{l}30 \mathrm{~min} \\
60 \mathrm{~min}\end{array}$ & $\begin{array}{l}-0.39^{\mathrm{a}} \pm 0.12 \\
-0.39^{\mathrm{a}} \pm 0.12\end{array}$ & $\begin{array}{c}0.81^{\mathrm{bB}} \pm 0.67 \\
0.22^{\mathrm{abAB}} \pm 0.69\end{array}$ & $\begin{array}{c}-0.45^{\mathrm{aAB}} \pm 0.61 \\
1.05^{\mathrm{bC}} \pm 0.34\end{array}$ & $\begin{array}{l}-0.57^{\mathrm{aA}} \pm 0.29 \\
-0.27^{\mathrm{aAB}} \pm 0.46\end{array}$ & $\begin{array}{c}4.13^{\mathrm{cC}} \pm 0.67 \\
-0.36^{\mathrm{aA}} \pm 0.46\end{array}$ \\
\hline & $2 \mathrm{mg} / \mathrm{L}$ & $\begin{array}{l}30 \mathrm{~min} \\
60 \mathrm{~min}\end{array}$ & $\begin{array}{l}-0.39^{\mathrm{ab}} \pm 0.12 \\
-0.39^{\mathrm{ab}} \pm 0.12\end{array}$ & $\begin{array}{l}0.57^{\mathrm{cAB}} \pm 0.67 \\
0.42^{\mathrm{bAB}} \pm 0.85\end{array}$ & $\begin{array}{l}-0.85^{\mathrm{aA}} \pm 0.38 \\
-0.74^{\mathrm{aA}} \pm 0.40\end{array}$ & $\begin{array}{l}0.22^{\mathrm{bcAB}} \pm 0.74 \\
-0.64^{\mathrm{aA}} \pm 0.53\end{array}$ & $\begin{array}{c}-0.79 \mathrm{aA} \pm 0.40 \\
1.57^{\mathrm{CB}} \pm 0.45\end{array}$ \\
\hline \multirow{4}{*}{$\mathrm{b}^{*}(-)$} & \multicolumn{2}{|c|}{ Control } & $8.58^{a} \pm 0.41$ & $10.29^{\mathrm{abAB}} \pm 1.04$ & $13.95^{\mathrm{cB}} \pm 2.38$ & $11.98^{\mathrm{bAB}} \pm 1.18$ & $15.75^{\mathrm{cD}} \pm 1.81$ \\
\hline & $0.5 \mathrm{mg} / \mathrm{L}$ & $\begin{array}{l}30 \mathrm{~min} \\
60 \mathrm{~min}\end{array}$ & $\begin{array}{l}8.58^{\mathrm{a}} \pm 0.41 \\
8.58^{\mathrm{a}} \pm 0.41\end{array}$ & $\begin{array}{c}10.24^{\mathrm{aAB}} \pm 0.98 \\
9.45^{\mathrm{abA}} \pm 0.48\end{array}$ & $\begin{array}{l}9.99^{\mathrm{aA}} \pm 0.85 \\
9.33^{\mathrm{abA}} \pm 0.83\end{array}$ & $\begin{array}{l}12.62^{\mathrm{bB}} \pm 1.23 \\
10.59^{\mathrm{bA}} \pm 1.30\end{array}$ & $\begin{array}{l}12.85^{\mathrm{aB}} \pm 0.66 \\
13.10^{\mathrm{cC}} \pm 1.17\end{array}$ \\
\hline & $1 \mathrm{mg} / \mathrm{L}$ & $\begin{array}{l}30 \mathrm{~min} \\
60 \mathrm{~min}\end{array}$ & $\begin{array}{l}8.58^{a} \pm 0.41 \\
8.58^{a} \pm 0.41\end{array}$ & $\begin{array}{l}11.47^{\mathrm{cB}} \pm 1.46 \\
10.70^{\mathrm{AB}} \pm 1.21\end{array}$ & $\begin{array}{l}9.39^{\mathrm{abA}} \pm 1.07 \\
13.32^{\mathrm{cB}} \pm 0.95\end{array}$ & $\begin{array}{c}10.52^{\mathrm{bcA}} \pm 1.16 \\
11.63^{\mathrm{bcAB}} \pm 1.13\end{array}$ & $\begin{array}{c}19.89^{\mathrm{dE}} \pm 1.01 \\
12.24^{\mathrm{bcBC}} \pm 1.20\end{array}$ \\
\hline & $2 \mathrm{mg} / \mathrm{L}$ & $\begin{array}{l}30 \mathrm{~min} \\
60 \mathrm{~min}\end{array}$ & $\begin{array}{l}8.58^{a} \pm 0.41 \\
8.58^{a} \pm 0.41\end{array}$ & $\begin{array}{c}10.57^{\mathrm{bAB}} \pm 1.11 \\
10.45^{\mathrm{abAB}} \pm 1.46\end{array}$ & $\begin{array}{c}10.03^{\mathrm{abA}} \pm 1.27 \\
10.55^{\mathrm{bA}} \pm 1.21 \\
\end{array}$ & $\begin{array}{l}10.85^{\mathrm{bAB}} \pm 1.37 \\
10.32^{\mathrm{abA}} \pm 1.32\end{array}$ & $\begin{array}{c}10.41^{\mathrm{abAB}} \pm 0.99 \\
14.80^{\mathrm{cCD}} \pm 1.36 \\
\end{array}$ \\
\hline \multirow{4}{*}{$\Delta \mathrm{E}(-)$} & \multicolumn{2}{|c|}{ Control } & $10.11^{\mathrm{a}} \pm 0.63$ & $12.33^{\mathrm{aAB}} \pm 1.38$ & $19.46^{\mathrm{bC}} \pm 3.39$ & $17.37^{\mathrm{bB}} \pm 2.49$ & $24.99^{\mathrm{cD}} \pm 2.07$ \\
\hline & $0.5 \mathrm{mg} / \mathrm{L}$ & $\begin{array}{l}30 \mathrm{~min} \\
60 \mathrm{~min}\end{array}$ & $\begin{array}{l}10.11^{\mathrm{a}} \pm 0.63 \\
10.11^{\mathrm{a}} \pm 0.63\end{array}$ & $\begin{array}{c}13.03^{\mathrm{aAB}} \pm 1.83 \\
10.81^{\mathrm{aA}} \pm 0.81\end{array}$ & $\begin{array}{l}12.63^{\mathrm{aA}} \pm 1.46 \\
11.12^{\mathrm{aA}} \pm 2.61\end{array}$ & $\begin{array}{c}17.31^{\mathrm{bB}} \pm 2.13 \\
14.83^{\mathrm{bAB}} \pm 2.18\end{array}$ & $\begin{array}{l}16.90^{\mathrm{aB}} \pm 1.00 \\
17.21^{\mathrm{bB}} \pm 1.96\end{array}$ \\
\hline & $1 \mathrm{mg} / \mathrm{L}$ & $\begin{array}{l}30 \mathrm{~min} \\
60 \mathrm{~min}\end{array}$ & $\begin{array}{l}10.11^{\mathrm{a}} \pm 0.63 \\
10.11^{\mathrm{a}} \pm 0.63\end{array}$ & $\begin{array}{c}14.58^{\mathrm{bB}} \pm 2.10 \\
13.13^{\mathrm{abAB}} \pm 1.89\end{array}$ & $\begin{array}{c}11.66^{\mathrm{abA}} \pm 1.91 \\
18.93^{\mathrm{cB}} \pm 1.74\end{array}$ & $\begin{array}{c}12.06^{\mathrm{abA}} \pm 1.21 \\
14.14^{\mathrm{bA}} \pm 1.95\end{array}$ & $\begin{array}{l}29.38^{\mathrm{cE}} \pm 1.24 \\
14.37^{\mathrm{bB}} \pm 2.09\end{array}$ \\
\hline & $2 \mathrm{mg} / \mathrm{L}$ & $\begin{array}{l}30 \mathrm{~min} \\
60 \mathrm{~min}\end{array}$ & $\begin{array}{l}10.11^{\mathrm{a}} \pm 0.63 \\
10.11^{\mathrm{a}} \pm 0.63\end{array}$ & $\begin{array}{l}13.28^{\mathrm{bAB}} \pm 2.03 \\
12.60^{\mathrm{aAB}} \pm 2.39\end{array}$ & $\begin{array}{c}11.71^{\mathrm{abA}} \pm 2.03 \\
13.01^{\mathrm{aA}} \pm 2.17\end{array}$ & $\begin{array}{c}13.12^{\mathrm{abA}} \pm 2.43 \\
12.07^{\mathrm{aA}} \pm 2.02\end{array}$ & $\begin{array}{c}11.77^{\mathrm{abAB}} \pm 1.66 \\
21.19^{\mathrm{bC}} \pm 2.53\end{array}$ \\
\hline \multirow{4}{*}{$\mathrm{BI}(-)$} & \multicolumn{2}{|c|}{ Control } & $9.14^{\mathrm{a}} \pm 0.57$ & $11.84^{\mathrm{aAB}} \pm 1.52$ & $19.62^{\mathrm{cB}} \pm 4.59$ & $16.06^{\mathrm{bBC}} \pm 2.35$ & $26.35^{\mathrm{dD}} \pm 3.71$ \\
\hline & $0.5 \mathrm{mg} / \mathrm{L}$ & $\begin{array}{l}30 \mathrm{~min} \\
60 \mathrm{~min}\end{array}$ & $\begin{array}{l}9.14^{\mathrm{a}} \pm 0.57 \\
9.14^{\mathrm{a}} \pm 0.57\end{array}$ & $\begin{array}{l}12.58^{\mathrm{aAB}} \pm 1.77 \\
10.36^{\mathrm{abA}} \pm 0.87\end{array}$ & $\begin{array}{l}11.80^{\mathrm{aA}} \pm 1.59 \\
9.69^{\mathrm{abA}} \pm 2.16\end{array}$ & $\begin{array}{c}16.64^{\mathrm{bC}} \pm 2.34 \\
13.02^{\mathrm{bAB}} \pm 2.24\end{array}$ & $\begin{array}{l}17.17^{\mathrm{aC}} \pm 0.91 \\
17.45^{\mathrm{cC}} \pm 2.65\end{array}$ \\
\hline & $1 \mathrm{mg} / \mathrm{L}$ & $\begin{array}{l}30 \mathrm{~min} \\
60 \mathrm{~min}\end{array}$ & $\begin{array}{l}9.14^{\mathrm{a}} \pm 0.57 \\
9.14^{\mathrm{a}} \pm 0.57\end{array}$ & $\begin{array}{c}14.11^{\mathrm{bB}} \pm 2.24 \\
12.46^{\mathrm{abAB}} \pm 2.00\end{array}$ & $\begin{array}{l}10.26^{\mathrm{aA}} \pm 1.91 \\
17.65^{\mathrm{cB}} \pm 1.65\end{array}$ & $\begin{array}{c}11.36^{\mathrm{abA}} \pm 1.34 \\
13.29^{\mathrm{bABC}} \pm 1.81\end{array}$ & $\begin{array}{l}33.25^{\mathrm{cE}} \pm 2.44 \\
13.92^{\mathrm{bB}} \pm 2.17\end{array}$ \\
\hline & $2 \mathrm{mg} / \mathrm{L}$ & $\begin{array}{l}30 \mathrm{~min} \\
60 \mathrm{~min}\end{array}$ & $\begin{array}{l}9.14^{\mathrm{a}} \pm 0.57 \\
9.14^{\mathrm{a}} \pm 0.57\end{array}$ & $\begin{array}{l}12.65^{\mathrm{bAB}} \pm 2.11 \\
12.24^{\mathrm{aAB}} \pm 2.67\end{array}$ & $\begin{array}{c}10.61^{\mathrm{abA}} \pm 1.98 \\
11.54^{\mathrm{aA}} \pm 2.11\end{array}$ & $\begin{array}{c}12.63^{\mathrm{abAB}} \pm 2.57 \\
11.14^{\mathrm{aA}} \pm 1.99\end{array}$ & $\begin{array}{c}11.02^{\mathrm{abAB}} \pm 1.67 \\
20.65^{\mathrm{bC}} \pm 2.73 \\
\end{array}$ \\
\hline
\end{tabular}

\footnotetext{
a-d: significant statistical differences for each treatment during storage time $(p<0.05) ;{ }^{A-E}$ : significant statistical differences between
} treatments within each storage time $(p<0.05)$. The values represent the mean \pm standard error. 


\subsection{Firmness}

Firmness is an important textural property for fresh vegetables and fruits. Changes in texture in fruits and vegetables can be caused by enzymatic and non-enzymatic processes. Treatment of ozone of fresh vegetables and fruit either by washing or in storage with gaseous ozone is shown to have a significant impact on texture [31]. The firmness decrease with time may correspond to the tissue damage caused by ozone. Onopiuk et al. [12] suggested that loss of firmness during storage reduces marketability of the product due to reduced attractiveness to the consumer.

In this study, firmness was slightly increased after 4 days of storage in all groups (Table 5). Fourteen days of mushrooms stored in an atmosphere with 0.5 and $1.0 \mathrm{mg} \mathrm{L}^{-1}$ ozone for 30 and $60 \mathrm{~min}$ contributed to a decrease in firmness compared to 4 days of storage. The greatest decrease in firmness was recorded in the control group and in mushrooms treated with 0.5 and $1 \mathrm{mg} \mathrm{L}^{-1}$ ozone for $30 \mathrm{~min}$ after 14 days of storage compared with day 0 . The highest values of firmness were found in samples treated with ozone at a concentration of $2 \mathrm{mg} \mathrm{L}^{-1}$ for 30 and $60 \mathrm{~min}$ after 14 days of storage.

Table 5. Impact of ozone dose, time of ozonization, and storage time on firmness (N) of Agaricus bisporus measured on $0,4,7,11$, and 14 days of storage at $2{ }^{\circ} \mathrm{C}$.

\begin{tabular}{|c|c|c|}
\hline Group & Days of Storage & Firmness (N) \\
\hline \multirow{5}{*}{ Control } & 0 & $15.25^{\mathrm{ab}} \pm 1.35$ \\
\hline & 4 & $19.59^{\mathrm{bAB}} \pm 1.99$ \\
\hline & 7 & $18.15^{\mathrm{bBCD}} \pm 2.98$ \\
\hline & 11 & $10.93^{\mathrm{aAB}} \pm 2.25$ \\
\hline & 14 & $10.95^{\mathrm{aBC}} \pm 1.75$ \\
\hline \multirow{5}{*}{$0.5 \mathrm{mg} \mathrm{L}^{-1} ; 30 \mathrm{~min}$} & 0 & $15.25^{b} \pm 1.35$ \\
\hline & 4 & $16.39^{\mathrm{bA}} \pm 1.37$ \\
\hline & 7 & $14.20^{\mathrm{bAB}} \pm 2.57$ \\
\hline & 11 & $9.25^{\mathrm{aA}} \pm 1.48$ \\
\hline & 14 & $5.89^{\mathrm{aA}} \pm 1.03$ \\
\hline \multirow{5}{*}{$0.5 \mathrm{mg} \mathrm{L}^{-1} ; 60 \mathrm{~min}$} & 0 & $15.25^{\mathrm{ab}} \pm 1.35$ \\
\hline & 4 & $18.02^{\mathrm{bcAB}} \pm 3.33$ \\
\hline & 7 & $21.60^{\mathrm{cD}} \pm 1.03$ \\
\hline & 11 & $12.67^{\mathrm{aABC}} \pm 2.02$ \\
\hline & 14 & $14.25^{\mathrm{abC}} \pm 2.58$ \\
\hline \multirow{5}{*}{$1.0 \mathrm{mg} \mathrm{L}^{-1} ; 30 \mathrm{~min}$} & 0 & $15.25^{b} \pm 1.35$ \\
\hline & 4 & $17.66^{\mathrm{bAB}} \pm 1.53$ \\
\hline & 7 & $13.23^{\mathrm{abA}} \pm 2.73$ \\
\hline & 11 & $14.02^{\mathrm{bBCD}} \pm 0.74$ \\
\hline & 14 & $9.51^{\mathrm{aAB}} \pm 2.47$ \\
\hline \multirow{5}{*}{$1.0 \mathrm{mg} \mathrm{L}^{-1} ; 60 \mathrm{~min}$} & 0 & $9.51^{\mathrm{aAB}} \pm 2.47$ \\
\hline & 4 & $21.35^{\mathrm{bB}} \pm 2.34$ \\
\hline & 7 & $16.65^{\mathrm{aABC}} \pm 3.15$ \\
\hline & 11 & $16.53^{\mathrm{aCD}} \pm 1.39$ \\
\hline & 14 & $16.50^{\mathrm{aC}} \pm 1.78$ \\
\hline \multirow{5}{*}{$2.0 \mathrm{mg} \mathrm{L}^{-1} ; 30 \mathrm{~min}$} & 0 & $15.25^{\mathrm{ab}} \pm 1.35$ \\
\hline & 4 & $16.49^{\mathrm{abA}} \pm 2.56$ \\
\hline & 7 & $18.90^{\mathrm{bCD}} \pm 3.46$ \\
\hline & 11 & $13.02^{\mathrm{aABC}} \pm 3.51$ \\
\hline & 14 & $17.46^{\mathrm{abC}} \pm 3.34$ \\
\hline \multirow{5}{*}{$2.0 \mathrm{mg} \mathrm{L}^{-1} ; 60 \mathrm{~min}$} & 0 & $15.25^{b} \pm 1.35$ \\
\hline & 4 & $17.26^{\mathrm{AB}} \pm 3.41$ \\
\hline & 7 & $19.23^{C D} \pm 3.66$ \\
\hline & 11 & $18.44^{\mathrm{D}} \pm 2.11$ \\
\hline & 14 & $17.21^{C} \pm 4.17$ \\
\hline
\end{tabular}

$\overline{{ }^{a}-c}$ : significant statistical differences for each treatment during storage time $(p<0.05) ;{ }^{A-D}$ : significant statistical differences between treatments within each storage time $(p<0.05)$. The values represent the mean \pm standard error. 
Ali et al. [25] noticed significant differences in firmness of ozone treated papaya and the control group. Kying and Ali [32] reported that ozonized papaya fruit were significantly firmer than the untreated fruit. At the end of the storage period, a significant softening in all the samples (red bell peppers) was observed [33]. However, research has shown that ozone treatment does not affect the firmness of various fruits, e.g., pears, grapes, and apples [8]. Lagnika et al. (2013) suggested that a decrease in firmness has a direct connection to activity of polyphenol oxidase and bacteria, which may refer to the visual browning.

\subsection{Total Phenolic Content (TPC) and Total Antioxidant Activity (TAA)}

Agaricus bisporus is a good source of many compounds with antioxidant properties, especially phenols [18]. Dhomodharan and Mirunalini [34] noticed that Agaricus bisporus could be examined as a natural food product with antioxidant activity. Phenolic compounds work similar to antioxidants, and activity is specified according to their chemical structure [35-37]. Ozone can cause a loss of antioxidant compounds due to its strong oxidizing activity [38]. Nevertheless, ozone treatment was noticed to have no influence on the phenolic content of fresh-cut iceberg lettuce [39]. The total phenolic content (TPC) and total antioxidant activity (TAA) are presented in Figures 1 and 2. The ozone concentration, ozonization time, and storage period induced statistically significant differences of TPC and TAA in all treatment groups of mushrooms. Alvarez-Parrilla et al. [36] received a TPC value of approx. $45.6 \mathrm{mg} / 100 \mathrm{~g}$, which is consistent with the results of this study, where on day 0, TPC in the control group was $45.37 \pm 0.58 \mathrm{mg} / 100 \mathrm{~g}$, and in the ozonized groups, were in the range from $41.19 \pm 0.23$ to $60.65 \pm 0.22 \mathrm{mg} / 100 \mathrm{~g}$. TPC values decreased statistically and significantly with storage time in all study groups. The lowest TPC values were recorded in the control group and in the groups ozonized for 30 and $60 \mathrm{~min}$ with $2 \mathrm{mg} \mathrm{L}^{-1}$ ozone concentration after 14 days of storage $(36.25,37.62$ and $37.59 \mathrm{mg} / 100 \mathrm{~g}$, respectively). The highest content $(47.14 \mathrm{mg} / 100 \mathrm{~g})$ of TPC was noticed in the group ozonized for $60 \mathrm{~min}$ at a concentration of $1 \mathrm{mg} / \mathrm{L}$ after 14 days of storage. According to Minas et al. [15], exposure to ozone for 72 and $144 \mathrm{~h}$ caused an increase in total phenolic content in kiwifruit as compared to the control group.

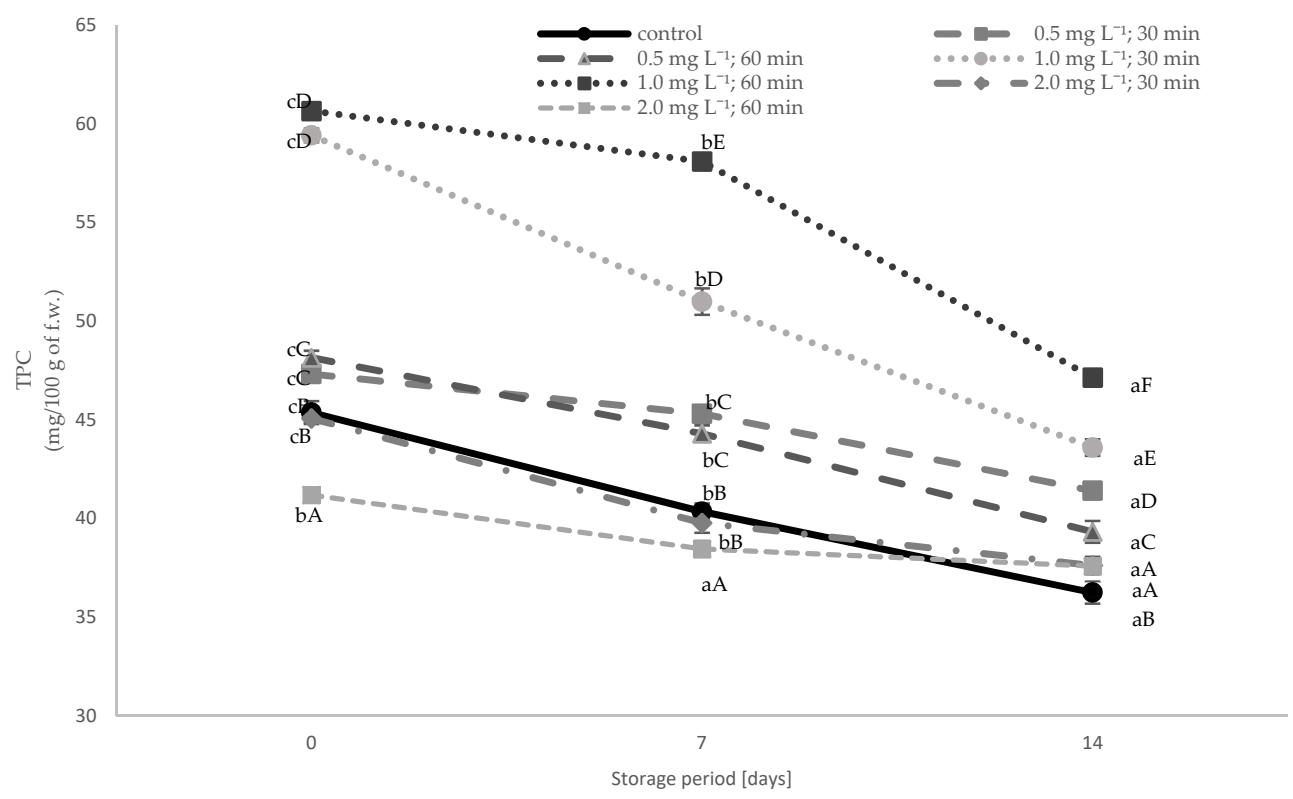

Figure 1. Effect of ozone dose, time of ozonization, and storage time on total phenolic content of Agaricus bisporus measured on 0,7 , and 14 days of storage at $2{ }^{\circ} \mathrm{C}$. a-c: significant statistical differences for each treatment during storage time $(p<0.05)$; A-F: significant statistical differences between treatments within each storage time $(p<0.05)$. The values represent the mean \pm standard error. 


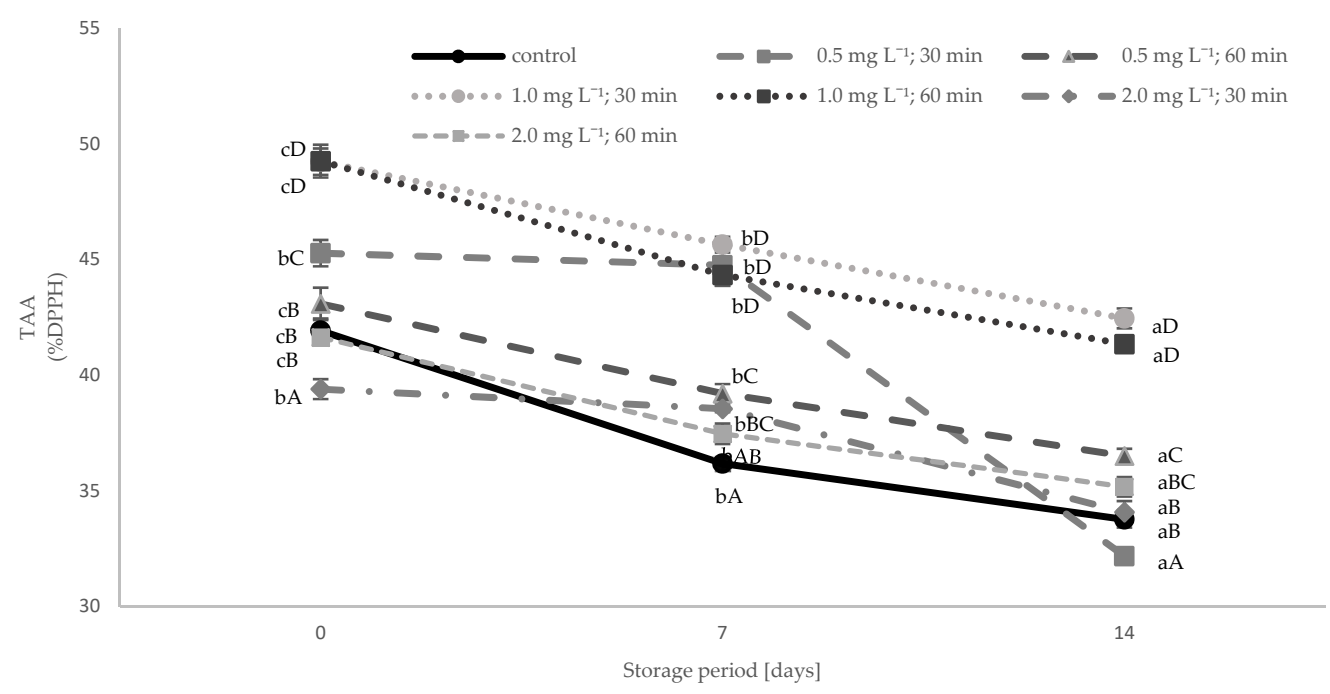

Figure 2. Effect of ozone dose, time of ozonization, and storage time on total antioxidant activity of Agaricus bisporus measured on 0,7 , and 14 days of storage at $2{ }^{\circ} \mathrm{C}$. a-c: significant statistical differences for each treatment during storage time $(p<0.05)$; A-D: significant statistical differences between treatments within each storage time $(p<0.05)$. The values represent the mean \pm standard error.

In this research, DPPH reagent was used to neutralize free radicals. TTA values decreased statistically and significantly with storage time in all study groups. At day 0 , a control sample of mushrooms showed total antioxidant activity (TTA) at a level of $41.92 \pm 0.53 \%$; during the 7 and 14 days of storage, it decreased by $5.75 \%$ and $8.16 \%$, respectively. Mushrooms from the group $\left(1 \mathrm{mg} \mathrm{L}^{-1}\right)$ subjected to ozonization within 30 and $60 \mathrm{~min}$ had a high ability to neutralize DPPH-free radicals (42.45 \pm 0.43 and $41.34 \pm 0.29$, respectively).

Minas et al. [15] noticed a statistically significant increase in TAA after $144 \mathrm{~h}$ of exposure to ozone in kiwifruit as compared to the control group. Onopiuk et al. [12] and Rodoni et al. [40] demonstrated that the presence of gaseous ozone increased total antioxidant activity in tomatoes during storage, and additionally, high concentrations of gas may inhibit enzymes that cause oxidation of phenolic compounds. Conversely, according to Botondi et al. [41], it is assumed that ozone induces loss of antioxidant compounds due to its strong oxidizing ability.

\section{Conclusions}

Storage of white button mushrooms at $2{ }^{\circ} \mathrm{C}$ for 14 days after ozonization with $0.5,1$, or $2 \mathrm{mg} \mathrm{L}^{-1}$ concentration and for durations of 30 or $60 \mathrm{~min}$ proved to be a factor causing a decrease in total phenolic content (TPC) and total antioxidant activity (TAA). However, treatment with ozone concentration of $1 \mathrm{mg} \mathrm{L}^{-1}$ for 30 and 60 min produces the best results. Treatment of ozone was beneficial for the maintenance of firmness. The most efficient preservation after 14 days of storage was seen in mushrooms ozonized for 30 or $60 \mathrm{~min}$ with a $2 \mathrm{mg} \mathrm{L}^{-1}$ concentration. Weight loss increased with the ozone dose and the storage time for all mushrooms samples. According to the measured color parameters, after 14 days of storage, it can be deduced that the application of ozone the external browning process speeds up during storage, while there is a retardation of the rate of internal browning. Outcomes of this study show that ozone may be used as an additional technology in fresh mushrooms, which does not cause large changes in quality and physical parameters of Agaricus bisporus. The use of ozone in food production permits us to define this technique as safe and environmentally friendly. 
Author Contributions: For conceptualization, M.Z., methodology, M.Z., software, M.Z. and M.M.-L.; validation, E.G.-H. and M.M.-L.; formal analysis, M.Z., investigation, M.Z., M.M.-L., and E.G.-H.; data curation, M.Z.; writing—original draft preparation, M.Z.; writing—review and editing, M.Z. All authors have contributed equally to the development of this article. All authors have read and agreed to the published version of the manuscript.

Funding: This research was financed by the Polish Ministry of Science and Higher Education through funds provided to the Institute of Human Nutrition Sciences, Warsaw University of Life Sciences (WULS) for scientific research.

Institutional Review Board Statement: Not applicable.

Informed Consent Statement: Not applicable.

Data Availability Statement: The data presented in this study are available on request from the corresponding author.

Conflicts of Interest: The authors declare no conflict of interest.

\section{References}

1. Mehta, B.K.; Jain, S.K.; Sharma, G.P.; Doshi, A.; Jain, H.K. Cultivation of button mushroom and its processing: A techno-economic feasibility. Int. J. Adv. Biotech. Res. 2011, 2, 201-207.

2. Chen, S.Y.; Yu, H.T.; Kao, J.P.; Yang, C.C.; Chiang, S.S.; Mishchuk, D.O.; Slupsky, C.M. Consumption of vitamin $\mathrm{D}_{2}$ enhanced mushrooms is associated with improved bone health. J. Nutr. Biochem. 2015, 26, 696-703. [CrossRef]

3. Ban, Z.; Li, L.; Guan, J.; Feng, J.; Wu, M.; Xu, X.; Li, J. Modified atmosphere packaging (MAP) and coating for improving preservation of whole and sliced Agaricus bisporus. J. Food Sci. Technol. 2014, 51, 3894-3901. [CrossRef]

4. Singh, P.; Langowski, H.-C.; Wani, A.; Saengerlaub, S. Recent advances in extending the self life of fresh Agaricus mushrooms: A review. J. Sci. Food Agric. 2010, 90, 1393-1402. [CrossRef]

5. Niksic, M.; Klaus, A.; Argyropoulos, D. Safety of foods based on mushrooms. In Regulating Safety of Traditional and Ethnic Foods; Prakash, V., Martin-Belloso, O., Keener, L., Astley, S., Braun, S., McMahon, H., Lelieveld, H., Eds.; Elsevier: Amsterdam, The Netherlands, 2016; pp. 421-439. [CrossRef]

6. Lagnika, C.; Zhang, M.; Nsor-Atindana, J.; Bashari, M. Effects of ultrasound and chemical treatments on white mushroom (Agaricus bisporus) prior to modified atmosphere packaging in extending shelf-life. J. Food Sci. Technol. 2014, 51, 3749-3757. [CrossRef]

7. Skog, L.J.; Chu, C.L. Effect of ozone on qualities of fruits and vegetables in cold storage. Can. J. Plant Sci. 2001, 81, 73-778. [CrossRef]

8. Pandiselvam, R.; Sunoj, S.; Manikantan, M.R.; Anjineyulu Kothakota; Hebbar, K.B. Application and kinetics of ozone in food preservation. Ozone Sci. Eng. 2017, 39, 115-126. [CrossRef]

9. Salu, A.K.; Yadav, B.K.; Santhakumaran, A. Effect of temperature and ozone treatment on the respiration of oyster mushroom. Int. J. Agric. Sci. Res. 2016, 6, 377-388.

10. Onopiuk, A.; Półtorak, A.; Wyrwisz, J.; Moczkowska, M.; Stelmasiak, A.; Lipińska, A.; Szpicer, A.; Zalewska, M.; Zaremba, R.; Kuboń, M.; et al. Impact of ozonisation on pro-health properties and antioxidant capacity of 'Honeoye' strawberry fruit. CYTA J. Food 2017, 15, 58-64. [CrossRef]

11. Escriche, I.; Serra, J.A.; Gómez, M.; Galotto, M.J. Effect of ozone treatment and storage temperature on physicochemical properties of mushrooms (Agaricus bisporus). Food Sci. Technol. Int. 2001, 7, 251-258. [CrossRef]

12. Onopiuk, A.; Szpicer, A.; Wojtasik-Kalinowska, I.; Wierzbicka, A.; Półtorak, A. Impact of ozonisation time and dose on health related and microbiological properties of rapanui tomatoes. Agriculture 2021, 11, 428. [CrossRef]

13. Tiwari, B.K.; O’Donnell, C.P.; Patras, A.; Brunton, N.P.; Cullen, P.J. Effect of ozone processing on anthocyanins and ascorbic acid degradation of strawberry juice. Food Chem. 2009, 113, 1119-1126. [CrossRef]

14. Abdel-Wahhab, M.A.; Sehab, A.F.; Hassanien, F.R.; El-Nemr, S.E.; Amra, H.A.; Abdel-Alim, H.A. Efficacy of ozone to reduce fungal spoilage and aflatoxin contamination in peanuts. J. Nuts Relat. Sci. 2011, 2, 01-14.

15. Minas, I.S.; Karaoglanidis, G.S.; Manganaris, G.A.; Vasilakakis, M. Effect of ozone application during cold storage of kiwifruit on the development of stem-end caused by Botrytis cinerea. Postharvest Biol. Technol. 2010, 58, 203-210. [CrossRef]

16. Gabler, F.M.; Smilanick, J.L.; Mansour, M.F.; Karaca, H. Influence of fumigation with high concentrations of ozone gas on postharvest gray mold and fungicide residues on table grapes. Postharvest Biol. Technol. 2010, 55, 85-90. [CrossRef]

17. De Souza, L.P.; Faroni, L.; Heleno, F.F.; Cecon, P.R.; Gonçalves, T.D.C.; da Silva, G.J.; Prates, L.H.F. Effects of ozone treatment on postharvest carrot quality. LWT 2018, 90, 53-60. [CrossRef]

18. Zalewska, M.; Marcinkowska-Lesiak, M.; Onopiuk, A. Physicochemical properties of Agaricus bisporus as affected by coating. J. Food Process. Pres. 2018, 42, e13419. [CrossRef]

19. Eissa, H.A.; Zohair, A. Quality and safety of halawa modified with mushroom. J. Sci. Food Agric. 2006, 86, 2551-2559. [CrossRef] 
20. Zalewska, M.; Marcinkowska-Lesiak, M.; Onopiuk, A.; Stelmasiak, A.; Półtorak, A. Modified atmosphere packaging for extending the shelf life of fresh Agaricus bisporus. J. Food Process Pres. 2018, 42, e13839. [CrossRef]

21. Kim, K.M.; Ko, J.A.; Lee, J.S.; Park, H.J.; Hanna, M.A. Effect of modified atmosphere packaging on shelf-life of coated, whole and sliced mushrooms. LWT 2006, 39, 364-371. [CrossRef]

22. Gao, M.; Feng, L.; Jiang, T. Browning inhibition and quality preservation of button mushroom (Agaricus bisporus) by essential oils fumigation treatment. Food Chem. 2014, 149, 107-113. [CrossRef] [PubMed]

23. Choi, Y.; Lee, S.M.; Chun, J.; Lee, H.B.; Lee, J. Influence of heat treatment on the antioxidant activities and polyphenolic compounds of Shiitake (Lentinus edodes) mushroom. Food Chem. 2006, 99, 381-387. [CrossRef]

24. Zhang, X.; Zhang, Z.; Wang, L.; Zhang, Z.; Li, J.; Zhao, C. Impact of ozone on a quality of strawberry during cold storage. Front. Agric. China 2011, 5, 356-360. [CrossRef]

25. Ali, A.; Ong, M.K.; Forney, C.F. Effect of ozone pre-conditioning on quality and antioxidant capacity of papaya fruit during ambient storage. Food Chem. 2014, 142, 19-26. [CrossRef] [PubMed]

26. Palou, L.; Crisosto, C.H.; Smilanick, J.L.; Adaskaveg, J.E.; Zoffoli, J.P. Effects of continuous 0.3 ppm ozone exposure on decay development and physiological responses of peaches and table grapes in cold storage. Postharvest Biol. Technol. 2002, $24,39-48$. [CrossRef]

27. Pandiselvam, R.; Subhashini, S.; Banuu Priya, E.P.; Anjineyulu Kothakota; Ramesh, S.V.; Shahir, S. Ozone based food preservation: A promising green technology for enhanced food safety. Ozone Sci. Eng. 2019, 41, 17-34. [CrossRef]

28. Andrés, A.I.; Timón, M.L.; Molina, G.; González, N.; Petrón, M.J. Effect of MAP storage on chemical, physical and sensory characteristics of "níscalos" (Lactarius delicious). Food Packag. Shelf Life 2014, 1, 179-189. [CrossRef]

29. Oliveira, F.; Sousa-Gallagher, M.J.; Mahajan, P.V.; Teixeira, J.A. Evaluation of MAP engineering design parameters on quality of fresh-sliced mushrooms. J. Food Eng. 2012, 108, 507-514. [CrossRef]

30. Wang, T.; Yun, J.; Zhang, Y.; Bi, Y.; Zhao, F.; Niu, Y. Effects of ozone fumigation combined with nano-film packaging on the postharvest storage quality and antioxidant capacity of button mushrooms (Agaricus bisporus). Postharvest Biol. Technol. 2021, 176, 111501. [CrossRef]

31. Prabha, V.; Barma, R.D.; Singh, R.; Madan, A. Ozone Technology in Food Processing: A Review. Trends Biosci. 2015, 8, $4031-4047$.

32. Kying, O.M.; Ali, A. Effect of ozone exposure on microbial flora and quality attributes of papaya (Carica papaya L.) fruit. J. Agron. Agric. Asp. 2016, JAAA-104. [CrossRef]

33. Horvitz, S.; Cantalejo, M.J. Effects of ozone and chlorine postharvest treatments on quality of fresh-cut red bell peppers. Int. J. Food Sci. Technol. 2012, 47, 1935-1943. [CrossRef]

34. Dhamodharan, G.; Mirunalini, S. A detail study of phytochemical screening, antioxidant potential and acute toxicity of Agaricus bisporus extract and its chitosan loaded nanoparticles. J. Pharm. Res. 2013, 6, 818-822. [CrossRef]

35. Basile, A.; Ferrara, L.; Del Pozzo, M.; Mele, G.; Sorbo, S.; Bassi, P.; Montesano, D. Antibacterial and antioxidant activities of ethanol extract from Paullinia cupana Mart. J. Ethnopharmacol. 2005, 102, 32-36. [CrossRef]

36. Alvarez-Parrilla, E.; de la Rosa, L.A.; Martínez, N.R.; González Aguilar, G.A. Total phenols and antioxidant activity of commercial and wild mushrooms from Chihuahua, Mexico. Cienc. Tecnol. Aliment. 2007, 5, 329-334. [CrossRef]

37. Radzki, W.; Sławińska, A.; Jabłońska-Ryś, E.; Gustaw, W. Antioxidant capacity and polyphenolics content in dried wild growing edible mushrooms. Int. J. Med. Mushrooms 2014, 16, 65-75. [CrossRef]

38. Karaca, H.; Velioglu, Y.S. Ozone Applications in fruit and vegetable processing. Food Rev. Int. 2007, 23, 91-106. [CrossRef]

39. Beltran, D.; Selma, M.V.; Marin, A.; Gil, M.I. Ozonated water extends the shelf life of fresh-cut lettuce. J. Agric. Food Chem. 2005, 53, 5654-5663. [CrossRef]

40. Rodoni, L.; Casadei, N.; Concellon, A.; Alicia, A.R.C.; Vicente, A.R. Effect of short-term ozone treatments on tomato (Solanum lycopersicum L.) fruit quality and cell wall degradation. J. Agric. Food Chem. 2010, 58, 594-599. [CrossRef]

41. Botondi, R.; Barone, M.; Grasso, C. Review into the effectiveness of ozone technology for improving the safety and preserving the quality of fresh-cut fruits and vegetables. Foods 2021, 10, 748. [CrossRef] 